\title{
Coding, stability, and non-spatial inputs in a modular grid-to-place cell model
}

\author{
David Lyttle ${ }^{1 *}$, Kevin Lin ${ }^{1,2}$, Jean-Marc Fellous ${ }^{1,3}$ \\ From Twenty First Annual Computational Neuroscience Meeting: CNS*2012 \\ Decatur, GA, USA. 21-26 July 2012
}

Grid cells in the medial entorhinal cortex $(\mathrm{mEC})$ and place cells in the hippocampus are paradigms for population coding of spatial information [1]. Both the spatiallyperiodic firing fields of grid cells and the spatially localized firing fields of place cells show systematic increases in spatial scale along the dorso-ventral axes of the $\mathrm{mEC}$ and hippocampus, respectively $[2,3]$, which has led to speculation that place field size is determined simply by the spatial scale of a place cell's grid cell inputs. However, in addition to receiving spatially-modulated entorhinal inputs, place cells receive contextual, non-spatial inputs from sources such as the amygdala and hypothalamus [4], which may be important in determining place cell firing properties. These non-spatial inputs are particularly prominent toward the ventral pole of the hippocampus [4], and thus could also play a role in producing dorso-ventral place cell differences.

In order to understand the relative contributions of grid cells and non-spatial inputs in determining place field size and stability, we propose a computational model of the hippocampal-entorhinal network that includes a modular organization of grid cell inputs arranged in order of increasing spatial scale, as is seen experimentally in the mEC. Our underlying place cell model is a firing-rate based model inspired by previous work [5], in which place fields are formed via competition between place cells. We also introduce a dorsoventral gradient in the amount of non-spatial input to place cells, with ventral cells receiving more input from non-spatial sources. Finally, we introduce heterogeneity into the firing rates of grid vertices within individual grid fields. This heterogeneity is observed in experimental recordings [6] but has received relatively

\footnotetext{
* Correspondence: dlyttle@math.arizona.edu

'Program in Applied Mathematics, University of Arizona, Tucson, AZ 85721, USA Full list of author information is available at the end of the article
}

little attention in experimental or theoretical work, despite its potential impact on place field stability.

Our main findings suggest that:

1.) For a wide range of parameters, the relative amounts of spatial and non-spatial inputs to place cells plays a more important role in determining place field size and stability than the spatial scale of grid cell inputs. This implies that the dorso-ventral gradient in place field size may reflect a dorso-ventral gradient in non-spatial inputs, rather than grid scale, and is agreement with prior suggestions of a functional distinction between the dorsal and ventral regions of the hippocampus [7].

2.) In our model, place fields are sensitive to changes in the firing rates of the grid vertices of individual grid cells, emphasizing the potential implications of this grid field heterogeneity for place field formation and stability.

\section{Acknowledgements}

Thanks to Brian Gereke and the Fellous lab for helpful discussions. Funding sources for this work include NIH training grant T32 GM084905, NSF grant DMS-0907927, and NSF: IIS grant 11117303.

\section{Author details}

'Program in Applied Mathematics, University of Arizona, Tucson, AZ 85721, USA. ${ }^{2}$ Department of Mathematics, University of Arizona, Tucson, AZ 85721, USA. ${ }^{3}$ Department of Psychology, University of Arizona, Tucson, AZ 85721, USA.

Published: 16 July 2012

\section{References}

1. Moser El, Kropff E, Moser MB: Place cells, grid cells, and the brain's spatial representation system. Annu Rev Neurosci 2008, 31:69-89.

2. Brun VH, Solstad T, Kjelstrup KB, Fyhn M, Witter MP, Moser El, Moser MB: Progressive increase in grid scale from dorsal to ventral medial entorhinal cortex. Hippocampus 2008, 18(12):1200-1212.

3. Kjelstrup KB, Solstad T, Brun VH, Hafting T, Leutgeb S, Witter MP, Moser El, Moser MB: Finite scale of spatial representation in the hippocampus. Science 2008, 321(5885):140-143.

4. Witter MP, Groenewegen HJ, Lopes da Silva FH, Lohman AH: Functional organization of the extrinsic and intrinsic circuitry of the parahippocampal region. Prog Neurobiol 1989, 33(3):161-253.
C Biomed Central

C 2012 Lyttle et al; licensee BioMed Central Ltd. This is an Open Access article distributed under the terms of the Creative Commons Attribution License (http://creativecommons.org/licenses/by/2.0), which permits unrestricted use, distribution, and reproduction in any medium, provided the original work is properly cited. 
5. de Almeida L, Idiart M, Lisman JE: The input-output transformation of the hippocampal granule cells: from grid cells to place fields. J Neurosci 2009, 29(23):7504-7512.

6. Hafting T, Fyhn M, Molden S, Moser MB, Moser El: Microstructure of a spatial map in the entorhinal cortex. Nature 2005, 436(7052):801-806.

7. Royer S, Sirota A, Patel J, Buzsaki G: Distinct representations and theta dynamics in dorsal and ventral hippocampus. J Neurosci 2010, 30(5):1777-1787.

doi:10.1186/1471-2202-13-S1-P141

Cite this article as: Lyttle et al:: Coding, stability, and non-spatial inputs in a modular grid-to-place cell model. BMC Neuroscience 2012 13(Suppl 1):P141.

Submit your next manuscript to BioMed Central and take full advantage of:

- Convenient online submission

- Thorough peer review

- No space constraints or color figure charges

- Immediate publication on acceptance

- Inclusion in PubMed, CAS, Scopus and Google Scholar

- Research which is freely available for redistribution

Submit your manuscript at www.biomedcentral.com/submit
() Biomed Central 